\title{
The Determination of Mineral and Heavy Metal Contents of Echinacea Species Cultivated in Turkey
}

\section{S. Ayșe ÇELIK ${ }^{* 1}$, Yüksel KAN ${ }^{1}$}

${ }^{1}$ Selcuk University, Faculty of Agriculture, Department of Medical Plants 42075-Konya.

Received: 05 May 2017 - Revised: 18 June 2017 - Accepted: 21 July 2017

\begin{abstract}
This study was carried out in the ecological conditions of Konya in 2013 and 2014 at Selcuk University Faculty of Agriculture, The Farm of Medicinal Plants. Mineral compositions ( $\mathrm{Na}, \mathrm{K}, \mathrm{Ca}, \mathrm{P}, \mathrm{Fe}, \mathrm{Zn}, \mathrm{Cu}, \mathrm{Mn} \mathrm{Al}$, $\mathrm{Cd}, \mathrm{Co}, \mathrm{Ni}, \mathrm{Cr}, \mathrm{Mo}$ and $\mathrm{Pb}$ ) were examined in five different species of Echinacea. The analyses of mineral compositions in Echinacea species were determined using NMKL 161 method and A Perkin-Elmer Optima 2000 inductively coupled plasma-optical emission spectrophotometer (ICP-OES) was used to analyze the elements to determine the mineral substances. The highest B, Ca, K, Na, P and S average contents according to the two-year mean values belonging to the herbs of Echinacea species were Echinacea purpurea var. double decker 135,029 ppm, Echinacea purpurea var. double decker 31185,018 ppm, Echinacea purpurea var. baby white swan 21968,858 ppm, Echinacea pallida var. pallida 104,742 ppm, Echinacea purpurea var. purpurea 2490,672 ppm and Echinacea paradoxa var. paradoxa 1754,594 ppm respectively. The herbs with the highest $\mathrm{Al}, \mathrm{Cd}, \mathrm{Co}, \mathrm{Cr}$, $\mathrm{Cu}, \mathrm{Fe}, \mathrm{Mn}, \mathrm{Pb}, \mathrm{Mo}, \mathrm{Ni}$ and $\mathrm{Zn}$ average contents according to the two-year mean values belonging to the herbs of Echinacea species were Echinacea purpurea var. baby white swan 432.195 ppm, Echinacea purpurea var. purpurea 0.111 ppm, Echinacea paradoxa var. paradoxa 0,395 ppm, Echinacea paradoxa var. paradoxa 2,615 ppm, Echinacea purpurea var. purpurea 22,535 ppm, Echinacea purpurea var. baby white swan 451.350 ppm, Echinacea paradoxa var. paradoxa 46.217 ppm, Echinacea paradoxa var. paradoxa 21.366 ppm, Echinacea purpurea var. purpurea 3.364 ppm, Echinacea paradoxa var. paradoxa $2.936 \mathrm{ppm}$ and Echinacea paradoxa var. paradoxa $22.218 \mathrm{ppm}$ respectively. The highest $\mathrm{B}, \mathrm{Ca}, \mathrm{K}, \mathrm{Na}, \mathrm{P}$ and $\mathrm{S}$ contents according to the two-year mean values of Echinacea roots were determined as Echinacea purpurea var. double decker 102,620 ppm, Echinacea purpurea var. purpurea 38805,7 ppm, Echinacea paradoxa var. paradoxa 20656,313 ppm, Echinacea pallida var. pallida 2062,226 ppm, Echinacea paradoxa var. paradoxa 2262,165 ppm and Echinacea paradoxa var. paradoxa $2181,838 \mathrm{ppm}$.
\end{abstract}

Keywords: Echinacea, Minerals, Heavy metals, Herb, Root.

\section{INTRODUCTION}

Compositeae (Asteraceae) is the richest family of flowering plants, representing by nearly 1000 genera and close to 20,000 species. About 133 genera and 1156 species belonging to family Asteraceae are grown in our country [1]. Echinacea species are perennial herbaceous plants in the Asteraceae family [2]. The Echinacea genus contains 11 species according to the review by Mc Keown (1999) [4]. The first culture studies of Echinacea plant in our country

*Corresponding Author E-mail: sacelik@selcuk.edu.tr

ISSN: 2148-6905 online /C 2017

DOI: $10.21448 / \mathrm{ijsm} .374170$ 
started in 2005 in the Selcuk University Faculty of Agriculture, The Farm of Medicinal Plants. Echinacea is a plant that can be grown up to $60-80 \mathrm{~cm}$ and starts to bloom from the second half of June. Leaf and stem of them are light hairy. The stem is cylindrical and consists of a very large number of side branches (25-30 on average). Approximately 250-300 seeds can be obtained in a mature flower bed. The seeds are about $5 \mathrm{~mm}$ long and $1.5 \mathrm{~mm}$ wide; it is angular and resembles a funnel. 1000 seed weights are about 5-6 g [5].

Echinacea species were used as wound healing externally and as a headache, gastric pain and cough cutter by the Native Americans $[3,6]$. It has proven anti-bacterial, anti-inflammatory, immune system strengthening and wound healing properties [7]. Especially in infectious diseases, it helps the body naturally increase resistance and pain. It is a preventive and therapeutic against colds, chill and influenza. The demand to Echinacea is increasing day by day both in our country and in the world [8]. Echinacea species are imported as drug or preparate and used in different pharmaceutical forms in the world.

This study was carried out in the ecological conditions of Konya in 2013 and 2014 at Selcuk University Faculty of Agriculture, The Farm of Medicinal Plants. Mineral compositions (macro elements, $\mathrm{Na}, \mathrm{K}, \mathrm{Ca}$, and $\mathrm{P}$; micro elements, $\mathrm{Fe}, \mathrm{Zn}, \mathrm{Cu}$, and $\mathrm{Mn}$; heavy metals, $\mathrm{Al}, \mathrm{Cd}$, $\mathrm{Co}, \mathrm{Ni}, \mathrm{Cr}, \mathrm{Mo}$ and $\mathrm{Pb}$ ) were investigated in herb and root specimens obtained from during full bloom period of five different species of Echinacea ((Echinacea purpurea var. purpurea (L.) Moench, Echinacea pallida var. pallida (Nutt.) Nutt., Echinacea paradoxa var. paradoxa (J.B.S. Norton) Britton, Echinacea purpurea var. baby white swan (L.) Moench and Echinacea purpurea var. double decker (L.) Moench)).

\section{MATERIAL and METHODS}

\subsection{Plant Material}

This study was carried out in the ecological conditions of Konya in 2013 and 2014 at Selcuk University Faculty of Agriculture, The Farm of Medicinal Plants. The seedlings of Echinacea species were growed in the greenhouse in 2012. Because echinacea is a perennial plant, analyses samples were not obtain from the farm the first year. But harvested analyses samples in the 2nd and 3rd years (2013-2014). The herb samples of five different species of Echinacea (Echinacea purpurea var. purpurea (L.) Moench, Echinacea pallida var. pallida (Nutt.) Nutt., Echinacea paradoxa var. paradoxa (J.B.S. Norton) Britton, Echinacea purpurea var. baby white swan (L.) Moench and Echinacea purpurea var. double decker (L.) Moench)) harvested during the full blooming period were dried in the shade and ground for analysis. During the short storage time, the plant samples were kept at $-20^{\circ} \mathrm{C}$ until use.

\subsection{Determination of Mineral and Heavy Metal Contents of Echinacea Species Cultivated in Turkey}

The NMKL 161 method was used to determine the mineral substances. For this purpose, ICP-OES (A Perkin-Elmer Optima 2000 inductively coupled plasma-optical emission spectrophotometer) was used. The determined minerals were $\mathrm{Al}, \mathrm{Co}, \mathrm{Mo}, \mathrm{Ca}, \mathrm{B}, \mathrm{Cd}, \mathrm{Cr}, \mathrm{Cu}$, $\mathrm{Fe}, \mathrm{K}, \mathrm{Mn}, \mathrm{Na}, \mathrm{Ni}, \mathrm{P}, \mathrm{Pb}, \mathrm{S}$ and $\mathrm{Zn}$. The results of the mineral substances were given in ppm $(\mathrm{mg} / \mathrm{kg})[9]$.

\subsection{Evaluation of Data}

Variance analyzes of the data obtained in the study were made by JMP-SAS 7.0 statistical package program and MSTAT-C statistical package program was used to make the letters. The statistically significant group tests between the mean values were determined by LSD $(0.01$ and 0.05 significance levels). 


\section{RESULTS and DISCUSSIONS}

\subsection{Minerals and Heavy Metals Results of Herbs}

Mineral compositions (macro elements, $\mathrm{Na}, \mathrm{K}, \mathrm{Ca}$, and $\mathrm{P}$; micro elements, $\mathrm{Fe}, \mathrm{Zn}, \mathrm{Cu}$, and $\mathrm{Mn}$; heavy metals, $\mathrm{Al}, \mathrm{Cd}, \mathrm{Co}, \mathrm{Ni}, \mathrm{Cr}, \mathrm{Mo}$ and $\mathrm{Pb}$ ) were determined five different species of Echinacea ((Echinacea purpurea var. purpurea (L.) Moench, Echinacea pallida var. pallida (Nutt.) Nutt., Echinacea paradoxa var. paradoxa (J.B.S. Norton) Britton, Echinacea purpurea var. baby white swan (L.) Moench and Echinacea purpurea var. double decker (L.) Moench)) The average values of mineral substances in the herbs obtained during the full blooming period in 2013 and 2014 are given in the tables section..

While the highest B (Boron) amount, according to two year mean values, was found in Echinacea purpurea var. double decker with $135,029 \mathrm{ppm}$, the lowest was found in Echinacea paradoxa var. paradoxa with 58,317 ppm. According to years, the mean values of 2014 was found to be higher with $120,306 \mathrm{ppm}$ with respect to the B amount. Although the highest Ca (Calcium) value of 2013 and 2014 mean values was found in 2014 with 28182.381 ppm, it took place in the same group with the average of 2013 according to the statistical evaluation. According to two-year mean values of herbs, the highest $\mathrm{Ca}$ amount was found in Echinacea purpurea var. double decker with 31185.018 ppm. When two-year mean values were analyzed, the highest K (potassium) concentration was found in Echinacea purpurea var. baby white swan with $21968.858 \mathrm{ppm}$ and the lowest was found in Echinacea paradoxa var. paradoxa with $18922.968 \mathrm{ppm}$. When 2013 and 2014 year mean values were analyzed, the highest $\mathrm{K}$ value was found to be higher as $20957.844 \mathrm{ppm}$ in 2014 . When the two-year mean values of the herbs were examined, the highest $\mathrm{Na}$ (sodium) concentration was found in Echinacea pallida var. pallida with 104,742 ppm and the lowest Na concentration was found in Echinacea purpurea var. baby white swan with 41,605 ppm. According to the data of 2013 and 2014, Na in 2013 was found to be 84.238 ppm higher than in 2014. The highest $\mathrm{P}$ (phosphor) intensity according to the two-year mean values was found as $2490,672 \mathrm{ppm}$ in E. purpurea var. purpurea. Although the average P values of 2013 and 2014 were statistically in the same group, the average value for 2014 was higher than 2013 with $2271.622 \mathrm{ppm}$. The highest value of the herbs were determined to be $1754.594 \mathrm{ppm}$ in Echinacea paradoxa var. paradoxa according to the mean values of S (sulphur) content for both year. Also, the lowest was found in Echinacea purpurea var. purpurea with $1087.522 \mathrm{ppm}$. When both years mean values were considered, S value of 2013 was found to be higher with 1437.124 ppm.

Results belonging to $\mathrm{Al}, \mathrm{Cd}, \mathrm{Co}, \mathrm{Cr}, \mathrm{Cu}, \mathrm{Fe}, \mathrm{Mn}, \mathrm{Pb}, \mathrm{Mo}, \mathrm{Ni}$ and $\mathrm{Zn}$ heavy metals are shown in "Tables" section. According to the average of the two-year values, the Al (aluminium) content intensity was found to be higher in 2013 with $324.281 \mathrm{ppm}$. Among the herbs, the highest $\mathrm{Al}$ amount was found in Echinacea purpurea var. baby white swan with $432.195 \mathrm{ppm}$. The lowest $\mathrm{Al}$ amount was found in Echinacea pallida var. pallida with 115,976 ppm. Looking at 2013 and 2014, while the Cd (cadmium) concentration was found to be higher in 2013 with $0.112 \mathrm{ppm}$, it was found to be lower in 2014 with $0.101 \mathrm{ppm}$. When two-year mean values of herbs were examined, the highest $\mathrm{Cd}$ amount was found in Echinacea purpurea var. purpurea with $0.111 \mathrm{ppm}$. According to the two-year mean values of the herbs, while the highest Co (cobalt) amount was found in Echinacea paradoxa var. paradoxa with 0,395 ppm, the lowest Co amount was found in Echinacea purpurea var. baby white swan with 0,316 ppm. When twoyear average values were considered the highest $\mathrm{Cr}$ (chromium) concentration was obtained in 2013 with 2,102 ppm. In the average of both two-year data of the herbs, the highest $\mathrm{Cr}$ concentration was obtained from Echinacea paradoxa var. paradoxa with $2.615 \mathrm{ppm}$ and lowest in Echinacea pallida var. pallida with $0.544 \mathrm{ppm}$. Considering the mean values of 2013 
and 2014, $\mathrm{Cu}$ (copper) was the highest with $17.095 \mathrm{ppm}$ in 2014. When the average of the twoyear data of herbs was taken into consideration, the $\mathrm{Cu}$ measure was obtained from Echinacea purpurea var. purpurea with $22,535 \mathrm{ppm}$ as the highest and Echinacea purpurea var. baby white swan with 11,581 ppm as the lowest. When the two-year mean values of the herbs were examined, the highest Fe (iron) amount was found in Echinacea purpurea var. baby white swan with 451,350 ppm and the lowest Fe amount was found in Echinacea paradoxa var. paradoxa with 158,181 ppm. When mean values of data taken between 2013 and 2014 were analyzed, Fe proportion was found to be higher with $369,942 \mathrm{ppm}$ in 2013. Mn (manganese) proportion in 2013 was found higher than 2014 with 32.988 ppm. In the average of two-year data of the herbs, the highest Mn amount was determined in Echinacea paradoxa var. paradoxa with $46.217 \mathrm{ppm}$ and the lowest in Echinacea pallida var. pallida with $9.126 \mathrm{ppm}$. When each year's $\mathrm{Pb}$ (Lead) mean values were examined, the average value in $2013(0,966 \mathrm{ppm})$ was found higher than 2014. When the two-year mean values of the herbs were examined, it was seen that Echinacea paradoxa var. paradoxa had the highest $\mathrm{Pb}$ concentration with 1,366 ppm and Echinacea pallida var. pallida had the lowest value with 0,583 ppm. Mo (molybdenum) amount in 2013 was found higher than 2014 with 2.268 ppm. Looking at the mean values of 2013 and 2014, the highest Mo amount was determined in Echinacea purpurea var. purpurea with 3,364 ppm. The lowest Mo amount was found in Echinacea purpurea var. double decker with 0,673 ppm. In the average of two-year data of the herbs, the highest $\mathrm{Ni}$ (nickel) mass was determined in Echinacea paradoxa var. paradoxa with $2,936 \mathrm{ppm}$ and the lowest in Echinacea pallida var. pallida with $0.941 \mathrm{ppm}$. Ni mass in 2013 was found higher than 2014 with $2.410 \mathrm{ppm}$. Zn (zinc) amount in 2013 was found higher than 2014 with $19.809 \mathrm{ppm}$. The highest Zn proportion was determined in Echinacea paradoxa var. paradoxa with $22.218 \mathrm{ppm}$ according to two-year mean values of herbs. The lowest $\mathrm{Zn}$ concentration was found in Echinacea pallida var. pallida with $14,710 \mathrm{ppm}$.

\subsection{Minerals and Heavy Metals Results of Roots}

Mineral compositions (macro elements, $\mathrm{Na}, \mathrm{K}, \mathrm{Ca}$, and $\mathrm{P}$; micro elements, $\mathrm{Fe}, \mathrm{Zn}, \mathrm{Cu}$, and $\mathrm{Mn}$; heavy metals, $\mathrm{Al}, \mathrm{Cd}, \mathrm{Co}, \mathrm{Ni}, \mathrm{Cr}, \mathrm{Mo}$ and $\mathrm{Pb}$ ) were examined in root samples obtained during full bloom period of five different species of Echinacea (Echinacea purpurea var. purpurea (L.) Moench, Echinacea pallida var. pallida (Nutt.) Nutt., Echinacea paradoxa var. paradoxa (J.B.S. Norton) Britton, Echinacea purpurea var. baby white swan (L.) Moench and Echinacea purpurea var. double decker (L.) Moench) The average values of mineral substances in the roots obtained during the full blooming period in 2013 and 2014 are given in the "Tables" section.

When the two-year average B values of roots were examined, it was found to be the highest at Echinacea purpurea var. double decker root with $102.620 \mathrm{ppm}$. B content value was found to be higher in 2013 with $74.440 \mathrm{ppm}$ according to the mean values at the roots in 2013 and 2014. According to years, Ca was found to be higher in 2013 with 37570.5 ppm, while it was found the highest in root of Echinacea purpurea var. purpurea with 38805.7 ppm when average two-year Ca concentration of roots was compared. When both years mean values were considered, K value in 2013 was found to be higher with $16853.219 \mathrm{ppm}$. When the two-year average K amounts of plant roots were examined, Echinacea paradoxa var. paradoxa root was found the highest with $20656.313 \mathrm{ppm}$. The lowest K mass was obtained from Echinacea purpurea var. baby white swan root with $10287.899 \mathrm{ppm}$. When the average values of the two years were examined, the proportion of $\mathrm{Na}$ in 2014 with $379.402 \mathrm{ppm}$ was higher than $\mathrm{Na}$ of 2013 (627.201 ppm). According to the two-year mean Na values of the herbs' roots, the highest was examined in Echinacea pallida var. pallida root with 2062.226 ppm and the lowest was found in Echinacea purpurea var. baby white swan with 605,483 ppm. When two-year mean values of $\mathrm{P}$ values were examined, the highest $\mathrm{P}$ concentration was found in Echinacea 
paradoxa var. paradoxa root with $2262.165 \mathrm{ppm}$. P concentration, according to years, was found to be higher with $1856.940 \mathrm{ppm}$ in 2013. According to years, the average $\mathrm{S}$ amount in 2013 was found to be higher with $1988.549 \mathrm{ppm}$. When the two-year average S amounts of plant roots were examined, it was found the highest in Echinacea paradoxa var. paradoxa root with $2181.838 \mathrm{ppm}$. The lowest S amount was found in Echinacea purpurea var. purpurea root with 1441.389 ppm.

When the data of heavy metals of $\mathrm{Al}, \mathrm{Cd}, \mathrm{Co}, \mathrm{Cr}, \mathrm{Cu}, \mathrm{Fe}, \mathrm{Mn}, \mathrm{Pb}, \mathrm{Mo}, \mathrm{Ni}$ and $\mathrm{Zn}$ in roots were determined, according to the average of the two-year values, the Al content mass was found to be higher in 2013 with $2197.75 \mathrm{ppm}$. Among the roots, the highest Al mass was found in Echinacea purpurea var. purpurea with $3966.88 \mathrm{ppm}$. The lowest Al mass was found in Echinacea purpurea var. double decker with $415.25 \mathrm{ppm}$. Looking at the two-year average Cd proportions, 2013 was identified higher than 2014 with $0,144 \mathrm{ppm}$. When the two-year mean values of the roots were studied, the highest and the lowest Cd values were respectively; in Echinacea purpurea var. purpurea root with $0.174 \mathrm{ppm}$ and in Echinacea purpurea var. purpurea root with $0.099 \mathrm{ppm}$. When two-year mean Co values of roots were studied, the highest was found in Echinacea purpurea var. purpurea root with $0,712191 \mathrm{ppm}$. Zn was found to be higher in 2013 with 0,496637 ppm according to the mean values at the roots in 2013 and 2014. Cr concentration, according to mean values of years, was found to be higher with 4,439 ppm in 2013. When the two-year mean values of the roots were determined, the highest $\mathrm{Cr}$ amount was found in Echinacea purpurea var. purpurea root as $7.755 \mathrm{ppm}$. When Cu mass of the roots were taken into account, the highest value was obtained from Echinacea purpurea var. purpurea root with $25.305 \mathrm{ppm}$. Cu amount was found to be higher with 24,548 ppm in 2014 among the mean values of 2013 and 2014. When the two-year average Fe mass of plant roots were considered, the highest was found in Echinacea purpurea var. purpurea root with $4137.818 \mathrm{ppm}$ and also the lowest in Echinacea purpurea var. double decker root with 528,373 ppm. When the average Fe concentrations of 2013 and 2014 were determined,, the average Fe concentration of 2013 was obtained to be higher with $2358.044 \mathrm{ppm}$. When the average Mn values of the two years were examined, the Mn amount of 2013 with 99,918 ppm was determined higher than Mn amount of 2014 (67.437 ppm). Looking at the average values of roots in 2013 and 2014, the highest Mn value was found in Echinacea purpurea var. purpurea root with 166.595 ppm and the lowest Echinacea purpurea var. double decker root with 49.624 $\mathrm{ppm}$. According to years, the average Pb proportion was found to be higher in 2013 with 2.440 ppm. When the two-year average Pb proportions of roots were studied, Echinacea purpurea var. purpurea root was found the highest with 4,508 ppm. The lowest $\mathrm{Pb}$ amount was found in Echinacea paradoxa var. paradoxa root with 1,089 ppm. Looking at the two-year mean values of the roots, the highest Mo mass was found in Echinacea purpurea var. purpurea root as $10.6734 \mathrm{ppm}$. The lowest Mo amount was obtained from Echinacea purpurea var. baby white swan root with $0.7236 \mathrm{ppm}$. According to the average of 2013-2014 values, Ni content was found to be higher in 2013 with $5.415 \mathrm{ppm}$. When the two-year Ni averages of roots were examined, the highest $\mathrm{Ni}$ amount was determined to be 9.731 in Echinacea purpurea var. purpurea root. When the average of the two-year values were examined with respect to $\mathrm{Zn}$ concentration, it was found to be higher in roots taken at 2013 with $50.068 \mathrm{ppm}$. When the twoyear average $\mathrm{Zn}$ amount of plant roots were considered, the highest was found in Echinacea purpurea var. purpurea root with 96,978 ppm and the lowest in Echinacea purpurea var. double decker root with $23,772 \mathrm{ppm}$.

The role of each element is different so that plants can nourish and sustain their vital activities. 16 of these elements are absolutely necessary for plants, these are; $\mathrm{C}, \mathrm{H}, 0, \mathrm{~N}, \mathrm{P}, \mathrm{K}$, $\mathrm{S}, \mathrm{Ca}, \mathrm{Mg}, \mathrm{Fe}, \mathrm{Zn}, \mathrm{Mn}, \mathrm{Cu}, \mathrm{B}, \mathrm{CI}$, and Mo. Some elements are important for some plants, these are; $\mathrm{Co}, \mathrm{Al}, \mathrm{Na}, \mathrm{Si}, \mathrm{Ni}$ and $\mathrm{V}$. In this study, considering the above information, minerals of $\mathrm{Al}$, $\mathrm{Co}, \mathrm{Mo}, \mathrm{Ca}, \mathrm{B}, \mathrm{Cd}, \mathrm{Cr}, \mathrm{Cu}, \mathrm{Fe}, \mathrm{K}, \mathrm{Mn}, \mathrm{Na}, \mathrm{Ni}, \mathrm{P}, \mathrm{Pb}, \mathrm{S}$ and $\mathrm{Zn}$ were determined in Echinacea 
herbs and roots. $\mathrm{Al}, \mathrm{Cd}, \mathrm{Cr}, \mathrm{Co}, \mathrm{Cu}, \mathrm{Fe}, \mathrm{Mn}, \mathrm{Pb}, \mathrm{Mo}, \mathrm{Ni}, \mathrm{Zn}$ of these elements are heavy metals and the others $(\mathrm{Ca}, \mathrm{Na}, \mathrm{B}, \mathrm{P}, \mathrm{S}$, and $\mathrm{K})$ are important for plants. According to obtained results, it is seen that heavy metals were not found in much amounts in the herbs. Nutrients are taken not only by root systems, but also by above-ground organs, especially by the leaves. Since leaves, stem and flowers are parts of the herb; the mineral proportions we have determined have been found to be higher in Echinacea species with higher leaf density (Echinacea purpurea var. purpurea (L.) Moench, Echinacea pallida var. pallida (Nutt.) Nutt., Echinacea paradoxa var. paradoxa (J.B.S. Norton) Britton, Echinacea purpurea var. baby white swan (L.) Moench and Echinacea purpurea var. double decker (L.) Moench) as seen in Table 1. Heavy metal concentration was determined to be higher in Echinacea roots according to results. Especially $\mathrm{Al}$ (aluminum) content were found high. It is thought that the reason of heavy metals to be high in the E. purpurea var. purpurea root is due to the fact that root structure of them are hairy root so the root ends are improved. At the same time, it is thought that the higher levels of heavy metals in the E. purpurea var. purpurea, E. purpurea var. baby white swan and E. purpurea var. double decker roots are due to the hairy root structures and therefore the roots propagate sideways. The heavy metal concentrations were observed lower because they have taproot structure and reach the depths of the soil.

\section{CONCLUSION}

Table 1 and Table 2 indicate that there were significant $(p<0.01)$ differences between the herbs and roots of Echinacea species with respect to their mineral compositions. The results of this study demonstrate that the aim of the study to compare of differences between the herbs and roots of Echinacea species. It was observed that the minerals of herbs and roots of Echinacea species were significantly differences. Echinacea spp. contain a lot of the minerals. Furthermore, the mineral composition of Echinacea samples showed a balance as good nutritional quality. However, further detailed studies on the mineral compositons of Echinacea spp are required. In conclusion, the Echinacea spp. contain many valuable minerals that is importance. 
1 Table-1. Mean values and groupings of mineral values of Echinacea herbs (ppm)

\begin{tabular}{|c|c|c|c|c|c|c|c|c|c|c|c|c|c|c|c|c|c|c|}
\hline Year & $\begin{array}{l}\text { Types of } \\
\text { Echinacea }\end{array}$ & Al & Co & Mo & $\mathrm{Ca}$ & B & Cd & $\mathrm{Cr}$ & $\mathbf{C u}$ & $\mathbf{F e}$ & $\mathbf{K}$ & Mn & $\mathrm{Na}$ & $\mathbf{N i}$ & $\mathbf{P}$ & $\mathbf{P b}$ & $\mathbf{S}$ & $\mathbf{Z n}$ \\
\hline \multirow{6}{*}{2013} & 1 & $\begin{array}{l}184,118 \\
\mathrm{~cd}\end{array}$ & $0,359 \mathrm{e}$ & $\begin{array}{l}3,663 \\
a b\end{array}$ & $\begin{array}{l}21611,681 \\
\text { cd }\end{array}$ & $66,619 \mathrm{~g}$ & $0,112 \mathrm{ab}$ & $0,643 \mathrm{c}$ & $8,979 \mathrm{e}$ & $228,719 d$ & $17482,814 \mathrm{e}$ & $9,345 \mathrm{f}$ & $\underline{117,663 \mathrm{a}}$ & $0,898 \mathrm{e}$ & $1879,808 \mathrm{e}$ & $0,412 \mathrm{c}$ & $1672,301 b$ & 14.957 \\
\hline & 2 & $225,044 \mathrm{c}$ & $0,382 \mathrm{~d}$ & $\underline{4,875 \mathrm{a}}$ & $\begin{array}{l}25892,648 \\
\text { bcd }\end{array}$ & $89,801 \mathrm{def}$ & $0,104 a b c$ & $2,195 b$ & $17,194 \mathrm{c}$ & $325,565 \mathrm{c}$ & $21365,645 b c$ & $25,213 \mathrm{~cd}$ & $89,913 \mathrm{ab}$ & $2,485 b$ & $2373,017 \mathrm{bc}$ & $1,015 b$ & $1193,171 \mathrm{ef}$ & 21.445 \\
\hline & 3 & $\underline{721,829 \mathrm{a}}$ & $0,308 \mathrm{~g}$ & $1,078 \mathrm{c}$ & $17199,606 \mathrm{~d}$ & $108,367 \mathrm{c}$ & $0,112 \mathrm{ab}$ & $2,124 b$ & $12,709 \mathrm{~d}$ & $\underline{713,692 \mathrm{a}}$ & $\underline{24091,280 \mathrm{a}}$ & $32,055 \mathrm{bc}$ & $53,547 \mathrm{ab}$ & $2,399 \mathrm{~b}$ & $2324,607 \mathrm{~cd}$ & $0,834 \mathrm{bc}$ & $1489,217 \mathrm{c}$ & 19.370 \\
\hline & 4 & $322,765 \mathrm{~b}$ & $0,324 \mathrm{f}$ & $0,737 \mathrm{c}$ & $\begin{array}{l}23132,006 \\
\text { cd }\end{array}$ & $92,731 \mathrm{de}$ & $0,107 \mathrm{abc}$ & $0,870 \mathrm{bc}$ & $10,350 \mathrm{e}$ & $381,326 b$ & $19628,651 d$ & $19,656 \mathrm{de}$ & $50,407 \mathrm{ab}$ & $1,445 \mathrm{~cd}$ & $2007,012 \mathrm{e}$ & $0,390 \mathrm{c}$ & $1124,540 \mathrm{f}$ & 16.278 \\
\hline & 5 & $\begin{array}{l}167,647 \\
\mathrm{~cd}\end{array}$ & $0,436 \mathrm{~b}$ & $0,986 \mathrm{c}$ & $\begin{array}{l}28679,245 \\
\text { bc }\end{array}$ & $39,904 \mathrm{~h}$ & $\underline{0,127 \mathrm{a}}$ & $\underline{4,677 \mathrm{a}}$ & $23,762 b$ & $200,410 d$ & $16969,524 \mathrm{e}$ & $\underline{78,669 \mathrm{a}}$ & $109,660 \mathrm{a}$ & $\underline{4,821 \mathrm{a}}$ & $2216,603 \mathrm{~cd}$ & $\underline{2,180 \mathrm{a}}$ & $1706,390 \mathrm{~b}$ & $\underline{26.995}$ \\
\hline & Mean & 324,281a & 0,356 & $2,268 \mathrm{a}$ & $23303,037 a$ & $79,484 b$ & $0,112 a$ & $2,102 a$ & $14,599 b$ & $369,942 a$ & $19907,583 b$ & 32,988a & 84,238 & $2,410 \mathrm{a}$ & $2160,209 a$ & $0,966 a$ & $1437,124 a$ & 19.809 \\
\hline \multirow{6}{*}{2014} & 1 & $47,835 \mathrm{e}$ & $0,423 \mathrm{c}$ & $0,612 \mathrm{c}$ & $\begin{array}{l}20330,502 \\
\text { cd }\end{array}$ & $83,194 \mathrm{ef}$ & $0,107 \mathrm{abc}$ & $0,445 \mathrm{c}$ & $22,241 b$ & $95,784 \mathrm{e}$ & $20660,910 \mathrm{bcd}$ & $8,906 \mathrm{f}$ & $91,821 \mathrm{ab}$ & $0,983 \mathrm{de}$ & $2493,166 \mathrm{ab}$ & $0,753 \mathrm{bc}$ & $987,354 \mathrm{~g}$ & 14.463 \\
\hline & 2 & $138,815 \mathrm{~d}$ & $0,356 \mathrm{e}$ & $\begin{array}{l}1,853 \\
\mathrm{bc}\end{array}$ & $\begin{array}{l}34035,310 \\
\text { ab }\end{array}$ & $162,137 b$ & $0,117 \mathrm{ab}$ & $0,599 \mathrm{c}$ & $\underline{27,875 \mathrm{a}}$ & $209,224 d$ & $21310,926 \mathrm{bc}$ & $24,800 \mathrm{~cd}$ & $96,216 \mathrm{ab}$ & $1,229 \mathrm{de}$ & $\underline{2608,327 \mathrm{a}}$ & $0,345 \mathrm{c}$ & $981,873 \mathrm{~g}$ & 22.577 \\
\hline & 3 & $142,561 \mathrm{~d}$ & $0,324 \mathrm{f}$ & $1,172 \mathrm{c}$ & $\begin{array}{l}20891,804 \\
\text { cd }\end{array}$ & $102,141 \mathrm{~cd}$ & $0,085 \mathrm{c}$ & $0,300 \mathrm{c}$ & $10,453 \mathrm{e}$ & $189,008 \mathrm{~d}$ & $19846,436 \mathrm{~cd}$ & $16,537 \mathrm{def}$ & $29,664 b$ & $1,208 \mathrm{de}$ & $1846,342 \mathrm{e}$ & $0,648 \mathrm{bc}$ & $1351,915 \mathrm{~d}$ & 18.798 \\
\hline & 4 & $210,213 \mathrm{c}$ & $\underline{0,452 \mathrm{a}}$ & $0,608 \mathrm{c}$ & $39238,030 \mathrm{a}$ & $\underline{177,327 \mathrm{a}}$ & $0,103 \mathrm{abc}$ & $0,655 \mathrm{c}$ & $14,509 \mathrm{~d}$ & $289,114 \mathrm{c}$ & $22094,535 b$ & $41,127 b$ & $104,710 \mathrm{ab}$ & $1,837 \mathrm{c}$ & $2207,149 \mathrm{~cd}$ & $0,793 b c$ & $1230,315 \mathrm{e}$ & 19.621 \\
\hline & 5 & $71,654 \mathrm{e}$ & $0,354 \mathrm{e}$ & $0,722 \mathrm{c}$ & $\begin{array}{l}26416,262 \\
\text { bcd }\end{array}$ & $76,731 \mathrm{fg}$ & $0,093 \mathrm{bc}$ & $0,553 \mathrm{c}$ & $10,397 \mathrm{e}$ & $115,952 \mathrm{e}$ & $20876,412 \mathrm{bcd}$ & $13,765 \mathrm{ef}$ & $57,703 \mathrm{ab}$ & $1,052 \mathrm{de}$ & $2203,125 \mathrm{~d}$ & $0,551 \mathrm{bc}$ & $\underline{1802,799 \mathrm{a}}$ & 17.441 \\
\hline & Mean & $122,215 b$ & 0,382 & 0,993a & 28182,381a & $120,306 a$ & $0,101 b$ & 1,306 & $17,095 \mathrm{a}$ & 179,816b & $20957,844 a$ & $21,027 b$ & 76,023 & $1,262 \mathrm{~b}$ & 2271,622a & 0,618a & 1270,851b & 18,580 \\
\hline \multicolumn{2}{|c|}{ LSD $_{\text {Herb }}$} & 44.04 & 0.001643 & 1.335 & 9782 & 13.22 & - & 1.451 & 1.909 & 55.52 & 1563 & 9.695 & 75.62 & 0.4928 & 168.5 & 0.5691 & 90.51 & 11.36 \\
\hline \multicolumn{2}{|c|}{ LSD $_{\text {Year }}$} & 76.27 & - & 2.312 & 11980 & 13.22 & 0.02845 & 1.451 & 1.909 & 55.52 & 1563 & 9.695 & - & 0.4928 & 168.5 & 0.5691 & 90.51 & - \\
\hline
\end{tabular}

2 Types of Echinacea; 1. E. pallida var. pallida, 2. E. purpurea var. purpurea, 3. E.purpurea var. baby white swan, 4. E. purpurea var. double decker, 5.

3 Echinacea paradoxa var. paradoxa 
5 Table-2. Mean Values and Groupings of Mineral Values of Echinacea Roots (ppm)

\begin{tabular}{|c|c|c|c|c|c|c|c|c|c|c|c|c|c|c|c|c|c|c|}
\hline Year & $\begin{array}{l}\text { Types of } \\
\text { Echinacea }\end{array}$ & Al & Co & Mo & $\mathbf{C a}$ & B & Cd & $\mathbf{C r}$ & $\mathrm{Cu}$ & $\mathbf{F e}$ & $\mathbf{K}$ & Mn & $\mathbf{N a}$ & $\mathbf{N i}$ & $\mathbf{P}$ & $\mathbf{P b}$ & $\mathbf{S}$ & $\mathbf{Z n}$ \\
\hline \multirow{6}{*}{2013} & 1 & $1995,19 b$ & $0,474 \mathrm{~b}$ & 3,2056 & $31370,54 \mathrm{~cd}$ & $26,239 \mathrm{~cd}$ & $0,146 \mathrm{~b}$ & $5,382 \mathrm{~b}$ & 18,420abcd & 2523,769 & $14174,932 \mathrm{c}$ & $97,373 b$ & $1724,250 \mathrm{c}$ & $5,983 \mathrm{~b}$ & $1504,835 \mathrm{e}$ & $2,989 \mathrm{~b}$ & $\underline{2350,287 \mathrm{a}}$ & $39.604 \mathrm{c}$ \\
\hline & 2 & $\underline{7238,52 \mathrm{a}}$ & $\underline{0,883 \mathrm{a}}$ & 1,1871 & $\underline{57735,36 a}$ & $29,171 \mathrm{c}$ & $\underline{0,239 a}$ & $\underline{13,868 \mathrm{a}}$ & $25,284 a b c$ & 7433,549 & $10115,795 \mathrm{e}$ & $\underline{272,786 a}$ & $561,455 f$ & $\underline{16,155 a}$ & $1217,353 \mathrm{f}$ & $\underline{7,247 \mathrm{a}}$ & $1311,088 \mathrm{f}$ & $142.233 \mathrm{a}$ \\
\hline & 3 & $1381,08 \mathrm{bc}$ & $0,268 \mathrm{c}$ & 0,7997 & $16533,75 \mathrm{e}$ & $25,200 \mathrm{cde}$ & $0,120 \mathrm{bcd}$ & $2,714 \mathrm{~cd}$ & $16,459 \mathrm{bcd}$ & 1372,948 & $11924,874 d$ & $54,501 \mathrm{cde}$ & $743,304 \mathrm{e}$ & $3,625 \mathrm{c}$ & $2167,370 \mathrm{c}$ & $1,198 \mathrm{de}$ & $2019,214 \mathrm{c}$ & $23.569 \mathrm{e}$ \\
\hline & 4 & $190,31 d$ & $0,494 \mathrm{~b}$ & 0,6770 & $43683,77 \mathrm{~b}$ & $\underline{179,552 \mathrm{a}}$ & $0,098 \mathrm{e}$ & $0,096 \mathrm{e}$ & $8,495 \mathrm{~cd}$ & 225,475 & $\underline{24476,304 a}$ & $41,274 \mathrm{de}$ & $47,980 \mathrm{~g}$ & $0,595 \mathrm{~d}$ & $2671,024 \mathrm{~b}$ & $0,481 \mathrm{e}$ & $2129,627 b c$ & $23.755 \mathrm{de}$ \\
\hline & 5 & $183,62 \mathrm{~d}$ & $0,367 \mathrm{bc}$ & 0,7398 & $38529,02 \mathrm{bc}$ & $112,037 \mathrm{~b}$ & $0,116 \mathrm{cde}$ & $0,135 \mathrm{e}$ & $6,173 d$ & 234,479 & $23574,192 \mathrm{a}$ & $33,653 \mathrm{e}$ & $59,018 \mathrm{~g}$ & $0,716 \mathrm{~d}$ & $1724,119 d$ & $0,286 \mathrm{e}$ & $2132,531 b c$ & $21.178 \mathrm{e}$ \\
\hline & Mean & $2197,75 a$ & 0,496637 & 1,32182 & 37570,5a & $74,440 \mathrm{a}$ & $0,144 a$ & 4,439a & 14,966ab & $2358,044 a$ & $16853,219 a$ & 99,918a & $627,201 b$ & $5,415 a$ & $1856,940 a$ & $2,440 a$ & 1988,549a & 50.068a \\
\hline \multirow{6}{*}{2014} & 1 & $604,07 \mathrm{~cd}$ & $0,529 \mathrm{~b}$ & 1,0436 & $24383,36 \mathrm{de}$ & 22,488 def & $0,133 b c$ & $2,528 \mathrm{~cd}$ & $15,164 \mathrm{bcd}$ & 822,011 & $10299,884 \mathrm{e}$ & $81,355 b c$ & $\underline{2400,203 \mathrm{a}}$ & $3,689 \mathrm{c}$ & $1029,314 \mathrm{~g}$ & $2,305 b c$ & $1752,724 d$ & $28.787 \mathrm{de}$ \\
\hline & 2 & $695,24 \mathrm{~cd}$ & $0,542 \mathrm{~b}$ & 20,1598 & $19876,03 \mathrm{e}$ & $21,081 \mathrm{f}$ & 0,110 cde & $1,643 \mathrm{de}$ & $25,326 a b c$ & 842,086 & $11969,075 d$ & 60,405 cde & $703,942 \mathrm{e}$ & $3,307 \mathrm{c}$ & $1459,487 \mathrm{e}$ & $1,770 \mathrm{~cd}$ & $1571,690 \mathrm{e}$ & $51.724 \mathrm{~b}$ \\
\hline & 3 & $1770,43 b$ & $0,379 b c$ & 0,6476 & $19337,41 \mathrm{e}$ & $21,989 \mathrm{ef}$ & $0,133 b c$ & $3,502 \mathrm{c}$ & 29,079ab & 2095,701 & $8650,925 \mathrm{f}$ & $70,810 \mathrm{bc}$ & $467,663 \mathrm{f}$ & $4,481 \mathrm{c}$ & $1831,122 \mathrm{~d}$ & $2,211 b c$ & $1365,101 \mathrm{f}$ & $27.267 \mathrm{de}$ \\
\hline & 4 & $640,19 \mathrm{~cd}$ & $0,484 \mathrm{~b}$ & 0,8731 & $19208,06 \mathrm{e}$ & 25,689 cde & $0,100 \mathrm{de}$ & $2,078 \mathrm{~cd}$ & $17,822 \mathrm{abcd}$ & 831,272 & $13322,171 \mathrm{c}$ & 57,974 cde & $1251,495 \mathrm{~d}$ & $3,412 \mathrm{c}$ & $1447,093 \mathrm{e}$ & $1,818 \mathrm{~cd}$ & $1770,757 \mathrm{~d}$ & $23.789 \mathrm{de}$ \\
\hline & 5 & $756,36 \mathrm{~cd}$ & $0,479 b$ & $\underline{3,9546}$ & $22157,66 \mathrm{e}$ & 25,476 cde & $0,130 \mathrm{bc}$ & $2,245 \mathrm{~cd}$ & $\underline{35,347 \mathrm{a}}$ & 910,891 & $17738,435 b$ & $66,638 \mathrm{~cd}$ & $2073,708 \mathrm{~b}$ & $3,927 \mathrm{c}$ & $\underline{2800,211 \mathrm{a}}$ & $1,893 \mathrm{~cd}$ & $2231,145 \mathrm{ab}$ & $32.894 \mathrm{~cd}$ \\
\hline & Mean & $893,25 b$ & 0,482621 & 5,33574 & $20992,5 b$ & $23,344 b$ & $0,121 b$ & $2,399 b$ & $24,548 a$ & $1100,392 b$ & $12396,098 \mathrm{~b}$ & $67,437 b$ & $1379,402 a$ & $3,763 b$ & $1713,445 b$ & $1,999 a$ & $1738,283 b$ & $32.892 b$ \\
\hline \multicolumn{2}{|c|}{ LSD ${ }_{\text {Herb }}$} & 953.7 & 0.2076 & 0.125 & 8352 & 3.983 & 0.02012 & 1.828 & 18.12 & 737.1 & 948.3 & 28.45 & 120 & 1.494 & 128.3 & 0.9145 & 153.7 & 9.158 \\
\hline \multicolumn{2}{|c|}{ LSD $_{\text {Year }}$} & 953.7 & - & - & 8352 & 3.983 & 0.02012 & 1.828 & 18.12 & 737.1 & 948.3 & 28.45 & 120 & 1.494 & 128.3 & 0.9145 & 153.7 & 9.158 \\
\hline
\end{tabular}

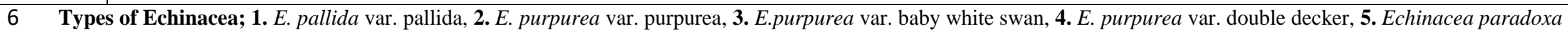

7 var. paradoxa 


\section{Conflict of Interests}

Authors declare that there is no conflict of interests.

\section{REFERENCES}

[1]. Miller, S. C., \& Yu, H. C. (Eds.). (2004). Echinacea: the genus Echinacea. Crc press.

[2]. Özcan, İ. İ. (2014). Farklı kültürel uygulamaların ekinezya türlerinin (Echinacea spp.) bazı verim ve kalite özelliklerine etkisi.

[3]. Bruneton, J. (1995). Pharmacognosy, phytochemistry, medicinal plants. Lavoisier publishing.

[4]. McKeown, K. A. (1999). A review of the taxonomy of the genus Echinacea. Perspectives on new crops and new uses, 482-489.

[5]. Kan, R. (2010). Konya ekolojik şartlarında yetiştirilen echinacea (E. pallida-E. purpurea) türlerinin uçucu yă̆ verimi ve bileşikleri üzerine farkl dozlarda uygulanan organik ve inorganik gübrelerin etkileri (Doctoral dissertation, Selçuk Üniversitesi Fen Bilimleri Enstitüsü).

[6]. Haksel, M. (2008). Echinacea 'Külah Çiçeği’, Türk Eczacılar Birliği Dergisi, 36-38.

[7]. Thomson PDR Staff (Ed.). (2004). PDR for herbal medicines. Physician's Desk Reference (PDR).

[8]. Gülpınar, A.R. (2009). Türkiye'de Kültürü Yapılan Echınacea Purpurea (L.) Moench ve Echınacea Pallıda (Nutt.) Nutt. Türleri Üzerinde Farmakognozik Araştırmalar, Yüksek Lisans Tezi, Ankara Üniversitesi Sağllk Bilimleri Enstitüsü.

[9]. Anonim, (1998) NMKL 161- Determination by atomic absorption spectrophotometry after wet digestion in a microwave oven. http://www.nmkl.org/index.php/en/webshop/item/metaller-2. 